\title{
Prevalence of food contamination with Listeria spp. in Kermanshah, Islamic Republic of Iran
}

A. Akya, ${ }^{7}$ F. Najafi, ${ }^{2}$ J. Moradi, ${ }^{1}$ Z. Mohebi ${ }^{3}$ and S. Adabagher ${ }^{1}$

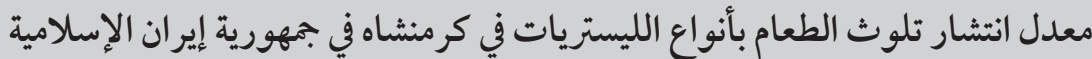

$$
\begin{aligned}
& \text { عليشا اكيا، فريد نجفي، زيلا مر ادي، زينب محبي، شيرين أداباقر }
\end{aligned}
$$

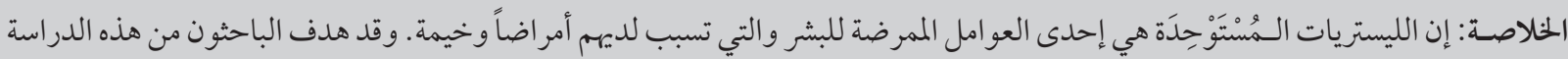

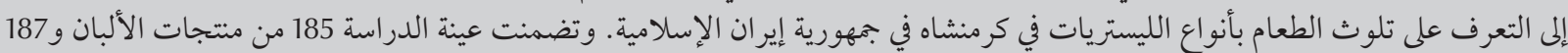

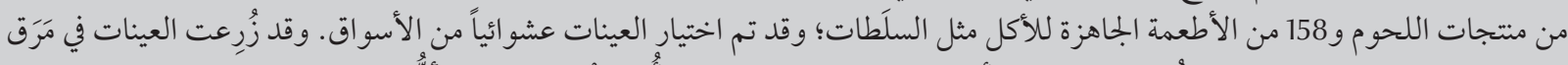

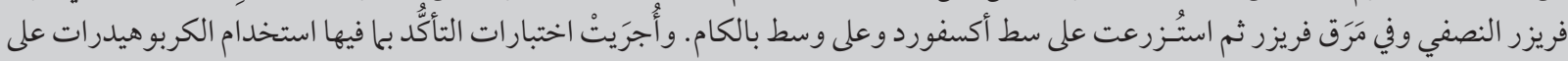

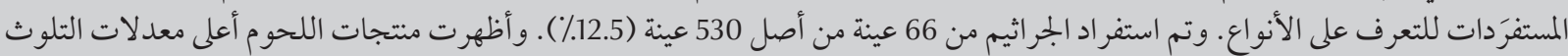

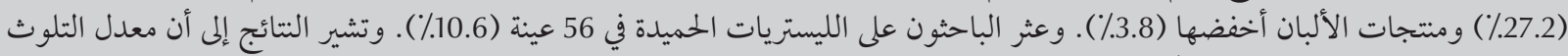

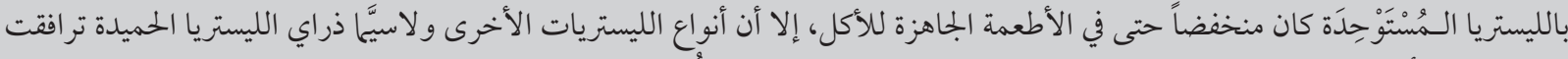

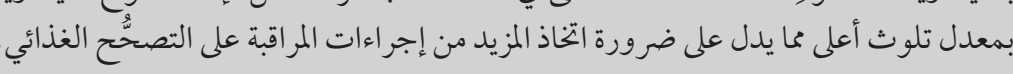

ABSTRACT Listeria monocytogenes is a human pathogen causing serious diseases. We aimed to determine food contamination with Listeria spp. in Kermanshah, Islamic Republic of Iran. Samples (185 dairy, 187 meat products and 158 ready-to-eat foods such as salads) were randomly collected from markets. After processing, samples were cultured in half-Fraser and Fraser broth followed by cultivation on PALCAM and Oxford media. Confirmatory tests including carbohydrate utilization were performed on isolates to determine species. Bacteria were isolated from 66/530 samples (12.5\%). Meat products showed the highest (27.2\%) and dairy products the lowest (3.8\%) contamination rates. L. innocua was found in 56 (10.6\%) samples, but L. monocytogenes was only found in 3 samples $(0.6 \%)$. The results indicate that the rate of contamination with L. monocytogenes, even for ready-to-eat foods, was low but for other Listeria spp., in particular strains of $L$. innocua, the rate of contamination was higher, suggesting that more control on food sanitation is required.

\section{Prévalence de la contamination alimentaire par Listeria spp. à Kermanshah (République islamique d'Iran)}

RÉSUMÉ Listeria monocytogenes est un agent pathogène humain à l'origine de maladies graves. Nous avons cherché à établir la prévalence de la contamination alimentaire par Listeria spp. à Kermanshah (République islamique d'Iran). Des échantillons(185 produitslaitiers,187 produitscarnéset158 platsprêtsàconsommer,commedessalades)ontétécollectés au hasard surles marchés. Après traitement, les échantillons ont été mis en culture dans un bouillon de Fraser-demi et de base Fraser puis repiqués sur gélose PALCAM et en milieu Oxford. Des tests de confirmation, y compris l'utilisation des glucides, ont été réalisés sur des isolats afin de déterminer l'espèce. Des bactéries ont été isolées dans 66 échantillons sur 530 (12,5\%). Les produits carnés étaient les plus fréquemment contaminés (27,2\%) tandis que les produits laitiers étaient les moins fréquemment contaminés (3,8\%). L. innocua a été identifiée dans 56 échantillons (10,6 \%), alors que L. monocytogenes n'a été retrouvée que dans trois échantillons $(0,6 \%)$. Ces résultats indiquent que le taux de contamination par L. monocytogenes, même dans les plats prêts à consommer, était faible, mais que pour les autres Listeria spp., en particulier les souches de L. innocua, le taux de contamination était plus élevé, suggérant qu'un contrôle plus strict de l'hygiène alimentaire est requis. 


\section{Introduction}

Listeria are Gram-positive, non-spore forming, facultatively anaerobic bacilli that are widespread in natural environments [1]. Although environmental reservoirs for Listeria spp. have not been determined, they are frequently found in soil, water, decaying plants and food processing environments [2,3]. Among Listeria species, L. monocytogenes is well known as a human pathogen [2]. It infects humans through ingestion of contaminated foods and can cause noninvasive diseases (gastroenteritis) and/ or serious invasive systemic diseases [4].

Given the increase in the elderly population in both developing and developed countries and the changes in food habits toward ready-to-eat products the incidence of listeriosis is increasing worldwide [5]. At the same time, increased numbers of international travellers and of food exchanges between countries means that food safety is a major health priority. We aimed to study the prevalence of contamination with Listeria spp. in a variety of food products obtained in Kermanshah, a city in the west of the Islamic Republic of Iran.

\section{Methods}

A total of 530 food samples were analysed: 185 dairy products, both pasteurized and non-pasteurized (various milks, cheese and ice creams), 187 meat products [minced meat, sausages and kielbasa (a type of Eastern European sausage or Polish sausage which is usually served uncooked)] and 158 ready-to-eat foods [oloveyh salad (a mayonnaise-based salad containing cooked chicken meat, potatoes, sour cucumber and green beans), green salads and fruit juices]. Samples were randomly collected from various food suppliers and distributors in Kermanshah. The method of storage at the outlet (refrigerated or non-refrigerated) and the general quality of samples at collection (appearance, colour and smell) were determined (scoring from 1 to 5, representing bad to excellent conditions). We also classified the samples according to the general conditions of cleanness and sanitation of the market outlet (scoring from 1 to 5 score representing bad to excellent conditions).

Samples $(200 \mathrm{~g})$ were collected in sterile plastic bags and taken to the laboratory. A $25 \mathrm{~g}$ sample of each was aseptically weighed and homogenized and mixed with $225 \mathrm{~mL}$ of half-Fraser broth (Merck). Solid samples were aseptically blended and homogenized [1] before adding to the half-Fraser broth medium. All equipment was sterile. The mixture (culture) was incubated at $30^{\circ} \mathrm{C}$ for 24 hours. From the mixture, $0.1 \mathrm{~mL}$ was added to $9.9 \mathrm{~mL}$ of Fraser broth medium (Merck) and incubated at $37^{\circ} \mathrm{C}$ for 24 hours. In order to isolate Listeria spp. colonies, the cultures were plated out on polymixin acriflavin lithium chloride ceftazidime asculin mannitol (PALCAM) agar and Oxford media (Merck) and incubated at $37^{\circ} \mathrm{C}$ for 24 to 48 hours. Five colonies with the characteristics of Listeria spp. (grey-green colonies with a black halo) were selected from each plate set and cultured on tryptone soy agar medium enriched with $0.6 \%$ yeast extract. The cultures were incubated at $37^{\circ} \mathrm{C}$ for 24 to 48 hours. In order to characterise the Listeria spp, differential tests including Gram staining, catalase, oxidase, motility at $25^{\circ} \mathrm{C}$, sheep-blood haemolysis, Christie-Atkins-MunchPetersen (CAMP), methyl red, VogesProskauer (MRVP) and carbohydrate utilization were carried out.

The data was analysed using Stata, version 11 software. Results are presented as mean and standard deviation (SD) and percentages. Student $t$-test and chi-squared tests were used for statistical analysis.

\section{Results}

Of the 530 samples the proportions scoring 1,2,3, 4 and 5 for general quality, i.e. from bad to excellent, were $2.3 \%$, $18.7 \%, 34.7 \%, 29.6 \%$ and $14.7 \%$ respectively. The lower scoring groups showed a significantly higher contamination rate $(P<0.05)$. However, no significant difference was found in contamination rates according to the sanitation score of the market outlets (Table 1).

\begin{tabular}{|c|c|c|c|c|}
\hline \multirow[t]{2}{*}{ Variable } & \multirow[t]{2}{*}{$\begin{array}{l}\text { No. of } \\
\text { samples }\end{array}$} & \multicolumn{2}{|c|}{$\begin{array}{l}\text { Contamination with } \\
\text { Listeria spp. }\end{array}$} & \multirow[t]{2}{*}{$P$-value } \\
\hline & & No. & $\%$ & \\
\hline Food quality score & & & & 0.001 \\
\hline 1 & 12 & 6 & 50.0 & \\
\hline 2 & 99 & 14 & 14.1 & \\
\hline 3 & 184 & 22 & 12.0 & \\
\hline 4 & 157 & 18 & 11.5 & \\
\hline 5 & 78 & 6 & 7.7 & \\
\hline Marketplace sanitation score & & & & $>0.05$ \\
\hline 1 & 31 & 7 & 22.6 & \\
\hline 2 & 66 & 8 & 12.1 & \\
\hline 3 & 188 & 22 & 11.7 & \\
\hline 4 & 193 & 23 & 11.9 & \\
\hline 5 & 52 & 6 & 11.5 & \\
\hline Total & 530 & 66 & 12.5 & \\
\hline
\end{tabular}

${ }^{a}$ Chi-squared test. 
A total of 66 samples (12.5\%) were contaminated with Listeria spp. From these 66 samples, 3 strains of $L$. monocytogenes, 56 strains of L. innocua, 5 strains of $L$. grayi and 2 strains of $L$. welshimeri were isolated.

Nearly two-thirds (63.8\%) of the 185 dairy product samples were pasteurized and the contamination rate for pasteurized and non-pasteurized dairy products was $1.5 \%$ and $5.0 \%$ respectively $(P=0.45)$. Overall, only $3.8 \%$ of the dairy samples were contaminated. The contamination rate of milk (10.2\%) was higher than ice cream $(1.5 \%)$ and cheese $(0 \%)$ ( Table 2).

Of the 187 meat product samples 27.3\% were contaminated with Listeria spp. (Table 2); minced meat papered for kebab showed the highest contamination rate $(60.3 \%)$.

Overall $5.1 \%$ of the 158 ready-toeat foods were contaminated with Listeria spp., $18.2 \%$ of meat-containing oloveyh salads, $5.4 \%$ of green salads and 1 sample (1.8\%) of fruit juice. However, none of them was contaminated with $L$. monocytogenes (Table 2).

\section{Discussion}

The results of this study showed that meat products were significantly more likely to be contaminated with Listeria spp. than other products. The higher contamination rate of meat products (for both Listeria spp. and L. monocytogenes), particularly minced meat such as sausages, suggests that the processing and preparation of meat may be carried out in poor hygienic conditions. Other factors such as equipment and additives may also play a role in contamination. Fortunately, this type of food is usually cooked thoroughly before use and consequently this process reduces the risk of listeriosis. The majority of samples tested were fresh products and this may reduce the likelihood of detectable contamination since there will be less time for bacterial growth.

The results showed a significant association between the contamination rate and the general quality of food products. The contamination rate was highest for products with low quality scores, indicating that the food materials and preparation play a key role in Listeria contamination.
Our results can be compared with the results of other studies in Islamic Republic of Iran and Asian countries. For instance, a study in Isfahan on different food products including meat, vegetables, dairy and ready-to-eat foods reported a $4.7 \%$ contamination rate with Listeria spp., which is lower than our result (12.5\%). However, contamination with L. monocytogenes was $1.2 \%$ in Isfahan, which is higher than our results (only 3 samples, 0.6\%) [6]. In a study in Pakistan, $10 \%-12.5 \%$ of fresh meat products were contaminated with Listeria spp. and this is similar to our result [7].

Our findings for the contamination level of dairy products are consistent with the results reported in Isfahan. In both studies dairy products showed a low contamination level (3.7\% in our study and $1.1 \%$ in Isfahan) and none of them were contaminated with $L$. monocytogenes [6]. In other research in the Islamic Republic of Iran, the rate of contamination of 500 raw milk samples with Listeria spp. was $2.2 \%$ [8], which is similar to our results. However, L. monocytogenes was found in $1.6 \%$ of raw milk samples and this strain was not found in our study. In that study the samples

\begin{tabular}{|c|c|c|c|c|c|c|}
\hline \multirow[t]{2}{*}{ Type of foods } & \multirow{2}{*}{$\begin{array}{c}\text { Total } \\
\text { samples } \\
\text { No. }\end{array}$} & \multicolumn{2}{|c|}{$\begin{array}{l}\text { Contamination with } \\
\text { Listeria spp. }\end{array}$} & \multicolumn{2}{|c|}{$\begin{array}{c}\text { Contamination with } L \text {. } \\
\text { monocytogenes }\end{array}$} & \multirow[t]{2}{*}{$P$-value } \\
\hline & & No. & $\%$ & No. & $\%$ & \\
\hline \multicolumn{7}{|l|}{ Dairy products } \\
\hline Ice cream & 67 & 1 & 1.5 & 0 & 0.0 & \multirow{3}{*}{0.007} \\
\hline Milk & 59 & 6 & 10.2 & 0 & 0.0 & \\
\hline Cheese & 59 & 0 & 0.0 & 0 & 0.0 & \\
\hline \multicolumn{7}{|l|}{ Meat products } \\
\hline Kielbasa ${ }^{\mathrm{a}}$ & 58 & 4 & 6.9 & 2 & 3.5 & \multirow{3}{*}{$<0.001$} \\
\hline Sausages & 56 & 3 & 5.4 & 0 & 0.0 & \\
\hline Minced meat & 73 & 44 & 60.3 & 1 & 1.4 & \\
\hline \multicolumn{7}{|l|}{ Ready-to-eatfoods } \\
\hline Oloveyh salad ${ }^{b}$ & 11 & 2 & 18.2 & 0 & 0.0 & \multirow{3}{*}{0.08} \\
\hline Fruit juice & 55 & 1 & 1.8 & 0 & 0.0 & \\
\hline Green salad & 92 & 5 & 5.4 & 0 & 0.0 & \\
\hline Total & 530 & 66 & 12.5 & 3 & 0.6 & $<0.001$ \\
\hline
\end{tabular}

${ }^{a}$ Type of sausage, usually served uncooked; ${ }^{b}$ Mayonnaise-based salad containing cooked chicken meat, potatoes, sour cucumber and green beans. ${ }^{c}$ Chi-squared (Fisher exact) test. 
tested were raw and non-pasteurized milk, which can explain the higher rate of contamination. In studies in Northern Ireland and Brazil the contamination rates of $L$. monocytogenes were reported to range from $10 \%-15.3 \%$ for raw milk and cheese and 9.5\%-18.3\% for raw food materials $[9,10]$. The difference may reflect the food habits in industrialized countries in terms of using ready-to-eat products particularly processed meats. The consumption of ready-to-eat foods, particularly meat products, is generally not popular in Islamic Republic of Iran. Nevertheless, $18.2 \%$ of oloveyh salad samples, which contain meat and are not subsequently cooked, were contaminated.

Studies in Asian countries also indicated low Listeria spp. contamination rates in food products. For instance, in a comprehensive study on 2686 food samples in China, $2.3 \%$ of the samples were contaminated with L. monocytogenes, which is slightly higher than our results. Moreover, similar to our findings, the contamination rate was found to be highest in meat products [11].

In conclusion, the rate of Listeria spp. contamination of food samples was comparatively low in Kermanshah. Meat products showed the highest and contamination rate and dairy products the lowest. L. monocytogenes was found in only 3 samples. Further studies on Listeria spp. are recommended to provide a better view of contamination rate and the routes of transmission for this foodborne pathogen.

\section{Acknowledgements}

Funding: We gratefully acknowledge the receipt of financial support from Kermanshah University of Medical Sciences to perform this research.

Competing interests: None declared.

\section{References}

1. Allerberger F. Listeria: growth, phenotypic differentiation and molecular microbiology. FEMS Immunology and Medical Microbiology, 2002, 35:183-189.

2. Vazquez-Boland JA et al. Listeria pathogenesis and molecular virulence determinants. Clinical Microbiology Reviews, 2001, 14:584-640.

3. Akya A, Thomas C, Pointon A. Listeria monocytogenes does not survive ingestion by Acanthamoeba polyphaga. Journal of Microbiology, 2010, 156:809-818.

4. Farber JM, Peterkin PI. Listeria monocytogenes, a food-borne pathogen. Microbiological Reviews, 1991, 55:476-511.

5. Koch J, Stark K. Significant increase of listeriosis in Germanyepidemiological patterns 2001-2005. Eurosurveillance : European Communicable Disease Bulletin, 2006, 11:85-88.

6. Jalali M, Abedi D. Prevalence of Listeria species in food products in Isfahan, Iran. International Journal of Food Microbiology, 2008, 122:336-340.
7. Mahmood MS, Ahmed AN, Hussain I. Prevalence of Listeria monocytogenes in poultry meat, poultry meat products and other related inanimates at Faisalabad. Pakistan. Journal of Nutrition, 2003, 2:346-349.

8. Moshtaghi $\mathrm{H}$, Mohamadpour A. Incidence of Listeria spp. in raw milk in Shahrekord, Iran. Foodborne Pathogens and Disease, 2007, 4:34-42.

9. Harvey J, Gilmour A. Occurrence of Listeria species in raw milk and dairy products produced in Northern Ireland. Journal of Applied Bacteriology, 1992, 72:119-125.

10. Da Silva MC, Hofer E, Tibana A. Incidence of Listeria monocytogenes in cheese produced in Rio de Janeiro. Brazil. Journal of Food Protection, 1998, 61:354-356.

11. Zhou X, Jiao X. Prevalence and lineages of Listeria monocytogenes in Chinese food products. Letters in Applied Microbiology, 2006, 43:554-559. 